carcinoma of the bronchus and mesothelioma of the pleura. Asbestos bodies were found in the lungs of about $20 \%$ of patients dying with carcinoma of the lung. They were found in more than $80 \%$ of men dying of mesothelioma of the pleura.

A history of an industrial occupation with exposure to asbestos was obtained from relatives, neighbours, or friends of about three-quarters of patients in whom asbestos bodies were found in the lungs at necropsy. Such a history was obtained for one-quarter of patients in whom asbestos bodies were not found in the lungs at necropsy.

It is concluded that there is evidence that exposure to asbestos, even though it may have been transient and many years previous, is an important factor in the aetiology of mesothelioma of the pleura. This conclusion gives cause for anxiety because of the increasing commercial use of asbestos.

We wish to thank Mrs. Yvonne Dudgeon and Mrs. Marion Simpson who worked untiringly with patience and tact to obtain occupational histories from patients or their relatives, friends, or neighbours. We are grateful to the records officers of Belfast hospitals for their help in searching out old notes and to many colleagues who have helped by referring patients to us. We wish to thank Dr. Merrett, of the Department of Social Medicine, for statistical advice. We are indebted for grants to the Stewart Friar Fund administered by the Faculty of Medicine of Queen's University, the British Empire Cancer Campaign, the Northern Ireland Hospitals Authority, the Royal Victoria Hospital Endowment Fund, and the Medical Research Council.

\section{REFERENCES}

Campbell, W. N. (1950). Amer. F. Path., 26, 473.

Doll, R. (1955). Brit. F. industr. Med., 12, 81.

Enticknap, J. B., and Smither, W. J. (1964). Ibid., 21, 20.

Gloyne, S. R. (1932). Lancet, 1, 1351.

Godwin, M. C. (1957). Cancer, 10, 298.

Hourihane, D. O'B. (1964). Thorax, 19, 268.

Keal, E. E. (1960). Lancet, 2, 1211.

Keal, E. E. (1960). Lancet, 2, 1211.

König, J. (1960). Arch. Gewerbepath. Gewerbehyg., 18, 159.

McCaughey, W. T. E. (1958). F. Path. Bact., 76, 517.

Wade, O. L., and Elmes, P. C. (1962). Brit. med. 7., 2, 1397.

Merewether, E. R. A. (1949). Annual Report of the Chief Inspector of Factories for the year 1947. H.M.S.O., London.

Owen, W. G. (1964). Brit. med. F., 2, 214.

Selikoff, I. J., Churg, J., and Hammond, E. C. (1964). f. Amer. med. Ass., 188, 22.

The Times (London), 5 March 1964, p. 17, col. 7.

The Times (London), 5 March 1964, p. 17, col. 7. S. (1962). 7. Path.

Bact., 84, 73.
Sleggs, C. A., and Marchand, P. (1960). Brit. F. industr. Med., 17, 260.

Williams, R., and Hugh-Jones, P. (1960). Thorax, 15, 109.

\title{
Serum Adenosine Deaminase in the Differential Diagnosis of Jaundice
}

\author{
D. M. GOLDBERG,* M.B., CH.B., B.SC.
}

Brit. med.F., 1965, 1, 353-355

The ability of most tissues of higher animals to convert adenosine to inosine and ammonia is due to a specific enzyme, adenosine deaminase. This enzyme was detected in whole blood and serum by Conway and Cooke (1939).

After the demonstration of elevated serum adenosine deaminase activity in tumour-bearing animals (Straub et al., 1957) and in human patients with bronchial carcinoma (Letnansky and Seelich, 1958) a study was made of serum adenosine deaminase activity in human patients suffering from a variety of malignant and non-malignant diseases (Koehler and Benz, 1962). The last of these authors reported a significant but non-diagnostic elevation of serum adenosine deaminase activity in the malignant group. On the other hand, the highest activities in the series were found among patients with infectious mononucleosis and hepatitis.

The present report concerns an investigation of serum adenosine deaminase activity in a large group of patients with and without jaundice, and it has been found that the estimation is of value in distinguishing between jaundice due to obstructive and hepatocellular causes.

\section{Materials and Methods}

Four categories of patient were studied.

Group A.-This group consisted of 52 healthy blood donors and patients prior to elective operations for herniae and varicose veins. Sex incidence was males 34 and females 18, and ages ranged from 2 to 79 years.

* Senior Registrar, Department of Biock mistry, Western. Infirmary, Glasgow, and the Department of Pathological Biochemistry, University of Glasgow.
Group B.-This group consisted of 50 patients suffering a variety of primary diseases, in the course of which the clinician suspected hepatic complications, but in whom neither jaundice nor any other clinical or laboratory parameter of such complications was detected after careful investigation. The cases were distributed as follows: cancer 22; myocardial infarction 4; congestive cardiac failure 4; reticuloses 4 ; muscular dystrophy 3 ; miscellaneous gastro-intestinal disorders 10 ; chronic alcoholism 3.

Group C.-This group consisted of 58 jaundiced patients in whom the cause was clearly obstructive. Cases with radiological evidence of stones in the biliary tract, or of hepatomegaly in known cancer cases, were included if the biochemical data were diagnostic. In all other cases within this group (48) the diagnosis was established at laparotomy or necropsy. In 30 cases the obstruction was associated with malignancy. The remainder were cases of cholelithiasis with or without associated cholecystitis.

Group D.-This group consisted of 55 jaundiced patients in whom the cause was clearly hepatocellular. This was established by histological examination in 28 . The remainder were cases of infectious hepatitis and cirrhosis showing the classical clinical and laboratory features of these conditions, together with four cases of acute jaundice following administration of known hepatotoxic drugs (chlorpromazine, two cases; para-aminosalicylic acid, two cases) subsiding on withdrawal of the suspected agent. In this group there were 26 cases of portal cirrhosis, 15 cases of infectious hepatitis, 4 cases of biliary cirrhosis, and 6 cases of miscellaneous subacute or chronic hepatocellular affections.

Serum adenosine deaminase activity was measured by a spectrophotometric method based on that of Solomon (1960). The optical density of a solution containing $20 \mu \mathrm{g}$. of adenosine per ml. of $0.1 \mathrm{M}$ phosphate buffer $p \mathrm{H} 7$ was read at $265 \mathrm{~m} \mu$ in a $1-\mathrm{cm}$. light path immediately after addition of serum (0.05 ml. $/ 3 \mathrm{ml}$. buffer-substrate mixture) and again after incubation at $37^{\circ} \mathrm{C}$. for one hour, the spectrophotometer being set at zero, using $0.05 \mathrm{ml}$. of serum in $3 \mathrm{ml}$. of $0.1 \mathrm{M}$ 
phosphate buffer $p H \quad 7$ as a blank which was incubated in parallel with the test solution. The units given in this communication represent the fall in optical density under the above conditions multiplied by $10^{3}$, and may be converted into International Units $(\mu \mathrm{m}$ adenosine deaminated $/ \mathrm{min}$./litre serum) by multiplying by the factor 123 . In the present communication the results of only the first analysis (mean of duplicates) is shown where more than one analysis was carried out on the same patient, together with data derived from the same serum specimen.

The following estimations were also carried out : Bilirubin (Malloy and Evelyn, 1937), alkaline phosphatase (King, Haslewood, Delory, and Beall, 1942), thymol turbidity (Maclagan, 1944), and zinc sulphate turbidity (Kunkel, 1947).

\section{Results}

Fig. 1 summarizes the values for serum adenosine deaminase activity in the present series. No differences referable to age or sex were discernible within group $A$. The individual values for serum adenosine deaminase activity of patients in group B overlap those of group A. The only two cases in group B exceeding a value of 50 units per $0.05 \mathrm{ml}$. had pyrexia, cachexia, and lymphadenopathy, and were thought to belong to the reticuloses. However, the difference in the mean values for groups $\mathrm{A}$ and $\mathrm{E}$ is significant $(0.05>\mathrm{P}>0.01)$.

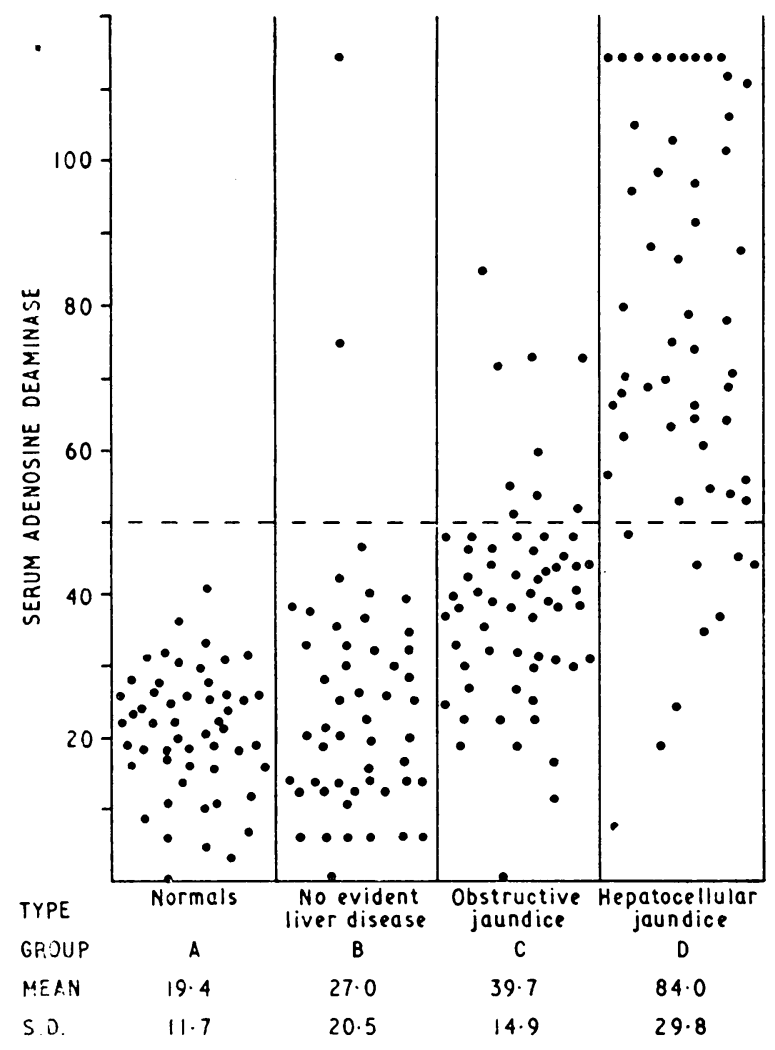

FIG. 1.-Distribution of serum adenosine deaminase activity

(unit $/ 0.05 \mathrm{ml}$.) in four groups of present series.

The mean for the obstructive group is significantly higher than that for group $\mathrm{A}(\mathrm{P}<0.01)$ and group $\mathrm{B}(0.05>\mathrm{P}>0.01)$, but only nine cases exceed an activity of 50 units $/ 0.05 \mathrm{ml}$.five of these had malignant infiltration of the liver, and four had cholelithiasis, with associated cholecystitis, the condition having progressed to an empyema of gall-bladder in one case. Analysis of those cases in group $\mathrm{C}$ in which the serum adenosine deaminase activity lay below 50 units $/ 0.05 \mathrm{ml}$. showed a tendency for those with a malignant cause (mean 42.4 units/ $0.05 \mathrm{ml}$.) to exhibit a higher value than those with a non- malignant cause (mean 37.5 units $/ 0.05 \mathrm{ml}$.) but the difference was not significant in the present series.

With few exceptions, the patients with hepatocellular jaundice had values for serum adenosine deaminase activity in excess of 50 units $/ 0.05 \mathrm{ml}$, and the difference in the mean value from that of the other three groups is highly significant $(\mathrm{P}<0.001)$. Of those patients in group $\mathrm{D}$ who failed to exceed this value two were cases of secondary biliary cirrhosis, one was a case of cardiac cirrhosis, three had compensated portal cirrhosis with normal serum transaminases, and three were cases of active portal cirrhosis with high serum transaminases. While the serum adenosine deaminase tended to be higher among patients with early severe infectious hepatitis and the terminal stages of portal cirrhosis, the highest value (315 units/ $0.05 \mathrm{ml}$.) was found in a patient with cirrhosis and ascites, in whom the serum bilirubin was $2.3 \mathrm{mg} . / 100 \mathrm{ml}$., and the serum transaminases were normal.

A correlation of the data for serum alkaline phosphatase with the value for serum adenosine deaminase activity is presented in Fig. 2. Results show a wide scatter, the correlation being a negative one with a value for the correlation coefficient $\mathrm{r}=-0.502$.

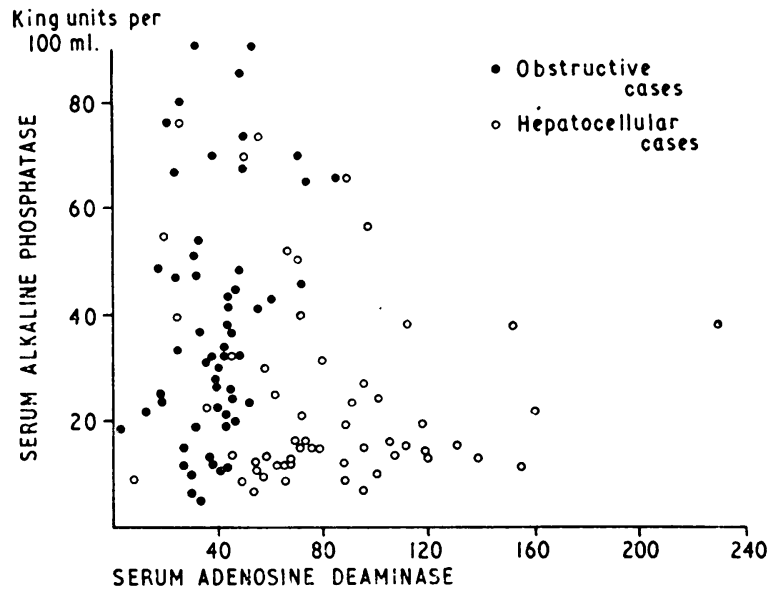

FIG. 2.-Correlation of serum adenosine deaminase activity with serum alkaline phosphatase activity in patients with obstructive and hepatocellular jaundice.

Figs. 3 and 4 show the correlation between serum adenosine deaminase activity on the one hand and serum thymol and zinc sulphate turbidities respectively on the other. In both instances the correlation is positive, the values for $\mathbf{r}$ being 0.311 and 0.518 respectively. Considering the diagnostic relationship between serum adenosine deaminase and serum

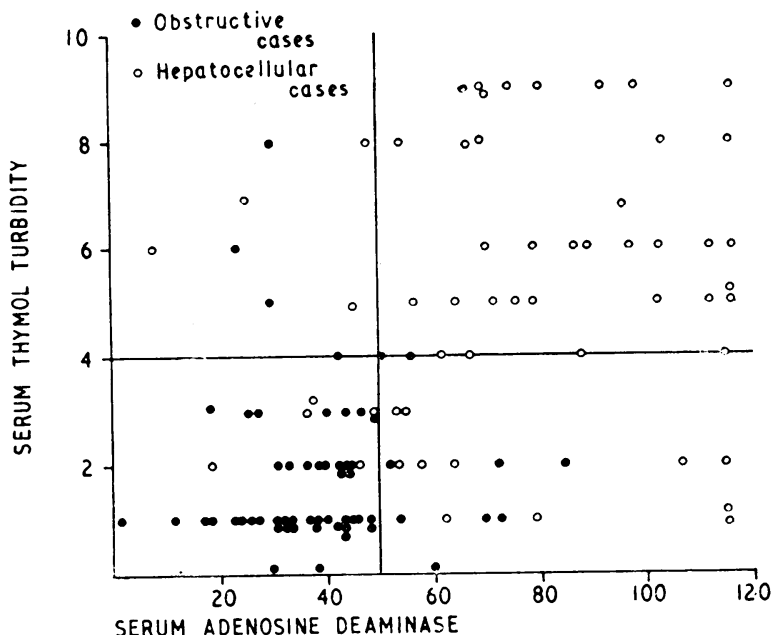

FIG. 3.-Correlation ol serum adenosine deaminase activity with serum thymol turbidity in jaundiced patients (upper normal limits defined by lines in diagram). 
thymol turbidity, it will be seen that 50 cases had both tests normal, 31 had both tests abnormal, and 25 had only one test abnormal. Similarly, on comparing serum adenosine deaminase with serum zinc sulphate turbidity it will be seen that 40 cases had both tests normal, 41 had both tests abnormal, and 28 had only one test abnormal.

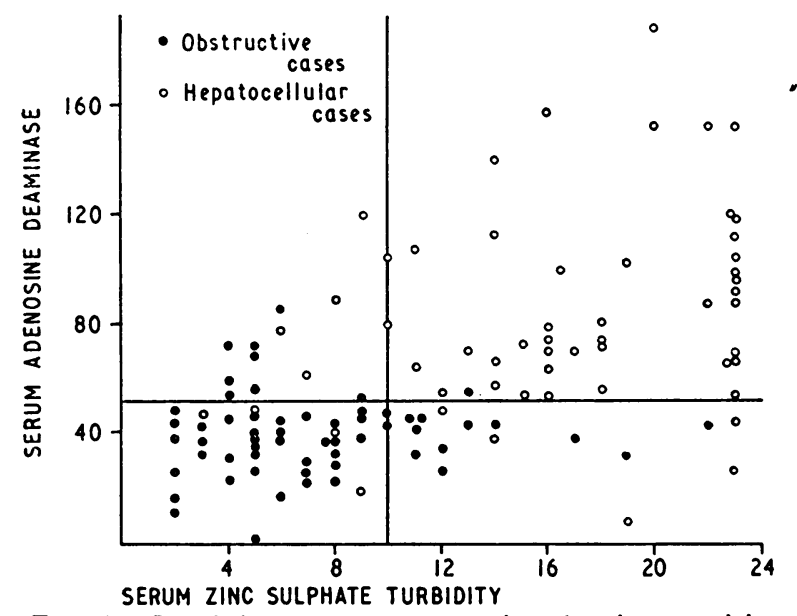

FIG. 4.-Correlation of serum adenosine deaminase activity with serum zinc sulphate turbidity in jaundiced patients (upper normal limits defined in lines in diagram).

The correlation of serum adenosine deaminase activity with serum bilirubin was highly complex, depending upon the disease process concerned, and the stage that had been reached at the time of examination. In general, the following summary applies. (a) Obstructive jaundice : no correlation whatever could be found. (b) Infectious hepatitis : the serum adenosine deaminase reaches a peak of activity before the serum bilirubin, so that in most cases during the first few days of observation the serum adenosine deaminase activity declines while the serum bilirubin is still rising. (c) Compensated cirrhosis: no correlation could be found. (d) Uncompensated or terminal cirrhosis : there is usually a steady increase in serum adenosine deaminase activity in parallel with a rising serum bilirubin concentration.

\section{Discussion}

The results of this investigation show a normal range for serum adenosine deaminase activity of $0-43$ units $/ 0.05 \mathrm{ml}$. However, a value of 50 units $/ 0.05 \mathrm{ml}$. would seem to be a more useful criterion for the separation of obstructive from hepatocellular jaundice, since only 9 out of 58 patients with the former diagnosis exceeded this value, and only 9 of 55 cases with the latter diagnosis failed to exceed this value in the first specimen examined. Moreover, only 2 of 50 ill nonicteric patients exceeded 50 units $/ 0.05 \mathrm{ml}$ for serum adenosine deaminase activity. The higher mean for group B is likely to be due to the large number of cancer patients in this group, since Koehler and Benz (1962) found a significantly higher mean in cancer patients compared with patients free of malignant and hepatic disease. Even when the two exceptional cases are omitted, the difference in the mean between group $A$ and $B$ is still significant at the $5 \%$ level of confidence.

It is not surprising that the serum adenosine deaminase appears to correlate negatively with alkaline phosphatase activity (Fig. 2) since this index shows the highest elevation in obstructive jaundice. Thus biliary obstruction does not seem to play a predominant part in the mechanism of serum adenosine deaminase elevation.

The correlation of serum adenosine deaminase activity with thymol and zinc sulphate turbidities is a positive one (Figs. 3 and 4), but the enormous variability and the low values for $r$ make it unlikely that the qualitative and quantitative changes in serum proteins responsible for the latter abnormalities (Maclagan and Bunn, 1947) are also responsible for the increased serum adenosine deaminase activity. The precise mechanisms involved must await further study.

Twelve cases in group $\mathrm{C}$ had alkaline phosphatase activities of less than 20 units $/ 100 \mathrm{ml}$; three had thymol turbidities greater than 4 units; and 12 had zinc sulphate turbidities greater than 10 units. Thirteen cases in group D had alkaline phosphatase activities greater than 30 units, 16 had thymol turbidities less than 4 units, and eight had zinc sulphate turbidities less than 10 units.

Since these represent anomalous findings on the basis of generally accepted criteria for discriminating between obstructive and hepatocellular jaundice, it seems justifiable to compare the "failure rate" of serum adenosine deaminase (18 cases) with that of alkaline phosphatase (25 cases), thymol turbidity (19 cases), and zinc sulphate turbidity (20 cases), in this series of 113 patients. This is not to imply that serum adenosine deaminase has equal value with these longestablished tests. On the contrary, the diagnosis can usually be reached by combining conventional laboratory procedures with sound clinical judgment. But in a minority of cases the serum adenosine deaminase assay may prove useful, particularly when the problem is to distinguish between obstruction and cirrhosis, and when the distinction cannot be made by existing biochemical methods.

\section{Summary}

Serum adenosine deaminase was estimated by a spectrophotometric method in over 200 subjects. Elevation of enzyme activity, outside the normal range, was found in approximately $85 \%$ of cases with hepatocellular jaundice, in $15 \%$ of cases with obstructive jaundice, and in $4 \%$ of cases suffering a variety of illnesses but in whom the hepato-biliary system was not affected. While the estimation of serum adenosine deaminase activity is unlikely to prove superior to existing procedures for the diagnosis of acute hepatitis, it is suggested that this estimation may have a useful part to play in distinguishing between biliary obstruction and chronic hepatitis.

I wish to thank Dr. E. B. Hendry for his encouragement of this work and his criticism of this manuscript.

\section{REFERENCES}

Conway, E. J., and Cooke, R. (1939). Biochem. 7., 33, 479. King, E. J., Haslewood, G. A. D., Delory, G. E., and Beall, D. (1942). Lancet, 1, 207.

Koehler, L. H., and Benz, E. J. (1962). Clin. Chem., 8, 133.

Kunkel, H. G. (1947). Proc. Soc. exp. Biol. (N.Y.), 66, 217.

Letnansky, K., and Seelich, F. (1958). Klin. W schr., 36, 826. Maclagan, N. F. (1944). Brit. f. exp. Path., 25, 234.

- and Bunn, D. (1947). Biochem. F., 41, 580.

Malloy, H. T., and Evelyn, K. A. (1937). f. biol. Chem., 119, 481.

Solomon, J. B. (1960). Biochem. F., 75, 278.

Straub, F. B., Stephaneck, O., and Acs, G. (1957). Biochimica, 22, 118. 